\title{
PERLINDUNGAN HUKUM TRANSAKSI BISNIS INTERNASIONAL PADA ERA PERDAGANGAN BEBAS
}

\author{
Wiwin Dwi Ratna, Zulvia Makka
}

Universitas Borneo Tarakan

Email: Zulviamakka@gmail.com

Abstrak

Kegiatan transaksi bisnis internasional saat ini bukanlah hal sulit, dengan berbagai kemajuan teknologi, dunia memberi kesempatan dan peluang yang cukup besar kepada para masyarakat internasional untuk dapat melakukan hubungan diantara mereka. Sejalan dengan berbagai kemudahan tersebut tidak menutup kemungkinan akan dapat menimbulkan permasalahan-permasalahan yang terjadi diantara mereka. Transaksi bisnis internasional merupakan kajian hukum privat, dimana dalam hukum privat, hukum memberikan peluang lebih luas untuk masing-masing pihak membuat, memperjanjikan dan melaksanakan klausul-klausul yang mereka buat. Namun tak dapat dipungkuri bahwa untuk dapat menjalankan kegiatan bisnis tersebut, para pihak harus dengan seksama mengerti dan memahami kaidah-kaidah hukum yang ada di Negara para pihak lawan. Hal tersebut sangat akan berpengaruh pada pelaksanaan dari perjanjian tersebut. Untuk itu sangat perlu bagi peneliti untuk memperjelas kajian mengenai perlindungan hukum transaksi bisnis internasional pada era perdagangan bebas.

Permasalahan sebagai berikut Prinsip Hukum transaksi Bisnis internasional pada era perdagangan bebas dan Kepastian Hukum pada transaksi Bisnis internasional. Metode yang digunakan adalah penelitian hukum normatif.

Penelitian ini menghasilkan Prinsip-prinsip hukum transaksi bisnis internasional dapat dijumpai pada kaidah hukum perjanjian internasional yang mengatur mengenai ketentuan-ketentuan transaksi bisnis internasional. Adapun ketentuan dalam konvensi internasional tersebut mengenai Contracts for the internasional Sale of Goods (CISG) dan the UNIDROIT Principle of International Contracts Tahun 1994 dan Kepastian hukum dalam kontrak bisnis internasional dapat dilihat dari sumber hukum kontrak bisnis internasional. Bahwasannya ketika pelaku usaha yang berbeda kewarganegaraan melakukan transaksi bisnis internasional, akan berkonseksuensi terhadap penundukan hukum salah satu negara pelaku usaha.

Kata Kunci : Perlindungan Hukum, Transaksi Bisnis Internasional, Perdagangan Bebas. 


\section{A. Latar Belakang}

Lalu lintas perdagangan saat ini sangat maju dengan pesatnya, pemenuhan kebutuhan hidup masyarakat didapat tidak hanya berasal dari wilayahnya sendiri. Kebutuhan yang terus meningkat, membawa masyarakat internasional semakin bebas memilih dan menentukan siapa dan apa yang bisa dianggapnya mampu melakukan pemenuhan kebutuhan hidupnya. Masyarakat internasional merupakan masyarakat dari Negara-negara merdeka yang tergabung dalam organisasi internasional ataupun Negaranegara yang memiliki dan atau telah melakukan hubungan internasional dengan Negara lainnya.

Melakukan kegiatan transaksi bisnis internasional saat ini bukanlah hal sulit, dengan berbagai kemajuan teknologi, dunia memberi kesempatan dan peluang yang cukup besar kepada para masyarakat internasional untuk dapat melakukan hubungan diantara mereka. Sejalan dengan berbagai kemudahan tersebut tidak menutup kemungkinan akan dapat menimbulkan permasalahan-permasalahan yang terjadi diantara mereka. Mengingat keberagaman masyarakat internasional tersebut sehingga tidak mudah mempersatukan maksud dan tujuan bersama dalam mewujudkan transaksi bisnis internasional yang kondusif.

Transaksi bisnis internasional merupakan kajian hukum privat, dimana dalam hukum privat, hukum memberikan peluang lebih luas untuk masing-masing pihak membuat, memperjanjikan dan melaksanakan klausulklausul yang mereka buat. Namun tak dapat dipungkuri bahwa untuk dapat menjalankan kegiatan bisnis tersebut, para pihak harus dengan seksama mengerti dan memahami kaidah-kaidah hukum yang ada di Negara para pihak lawan. Hal tersebut sangat akan berpengaruh pada pelaksanaan dari perjanjian tersebut.

Peraturan hukum serta kebijakan Negara akan dapat mempengaruhi kegiatan bisnis yang terjadi diantara mereka, sehingga beberapa investor asing khususnya lebih sedikit berhati-hati dalam melakukan transaksi bisnis, 
dengan demikian para pihak dalam transaksi bisnis internasional hendaknya mendapat perlindungan hukum yang sepantasnya dari beberapa kemungkinan-kemungkin pergolakan perekonomian dan kebijakan di Negara tempat dimana melakukan investasi.

Pelaku usaha (subjek hukum kontrak bisnis internasional) akan dihadapkan pada sebuah problem dalam penentuan hukum yang akan digunakan dalam kontrak bisnis internasional. Hal tersebut sangat mungkin terjadi ketika kedua pelaku usaha berasal dari negara yang menganut sistem hukum yang berbeda. Misalnya sistem hukum civil law dan common law atau anglo saxon dan Eropa Kontinental.

Ketika kaidah-kaidah hukum perdata internasional diberlakukan dalam penyelesaian sebuah sengketa kontrak bisnis internasional, maka salah satu pihak akan merasa terpaksa menundukkan diri terhadap satu hukum asing yang sebelumnya mungkin tidak diketahuinya dan didiharapkan untuk dijadikan kaidah hukum penyelesaian sengketa tersebut. Kontrak bisnis internasional sering disebut dengan istilah kontrak bisnis transnasional atau cross-border business contract. Terkadang, istilah Internasional dalam kalimat transaksi bisnis internasional sedikit rancu, yang kemudian menimbulkan sebuah pertanyaan apakah perbuatan hukum yang mereka lakukan akan berdampak dan diatur serta tunduk dalam hukum internasional. Untuk itu sangat perlu bagi peneliti untuk memperjelas kajian mengenai perlindungan hukum transaksi bisnis internasional pada era perdagangan bebas

Dari pemaparan diatas, maka dapat diidentifikasi permasalahan sebagai berikut Prinsip Hukum transaksi Bisnis internasional pada era perdagangan bebas dan Kepastian Hukum pada transaksi Bisnis internasional.

B. METODOLOGI 
Secara ilmiah penelitian ini, maka dalam melakukan penelitian ini menggunakan metode penilitan dianggap yang sesuai dengan judul dan pembahasan pada penelitian ini.

Jenis Penelitian ini adalah penelitian Hukum Normatif dimana peneliti akan menggunakan sumber dan bahan penelitian berasal dari peraturan perundang-undangan, buku-buku / literature hukum, serta penelitianpenelitian sebelumnya baik yang telah dipublikasi dalam jurnal, perpustakaan, baik secara online maupun hardcopy, sehingga dapat menjawab isu hukum yang ada dalam penelitian hukum ini secara sistematis dan dapat dipertanggungjawabkan secara ilmiah. Guna menjawab permasalahan hukum yang diteliti secara utuh, maka penelitian hukum normative tidak saja hanya peraturan perundang-undangan namun juga mencakup asas-asas hukum, sinkronisasi hukum, sejarah hukum dan perbandingan hukum.

Pendekatan penelitian yang peneliti gunakan kali ini adalah metode pendekatan perundang-undangan (statute Approach) dan pendekatan konseptual ( conceptual approach). Kedua pendekatan ini, menurut peneliti sudah cukup untuk menjawab dan menyelesaikan permasalah dalam isu hukum pada penelitian ini.

Selain jenis dan pendekatan penelitian, dalam penelitian hukum sangat penting untuk melakukan inventarisasi peraturan perundangundangan adn bahan-bahan hukum yang sangat diperlukan dalam memperkaya alasan, alibi, maupun penjelasan sehingga penafsiran hukum yang menyimpang dapat diminimalisasi. Pengumpulan bahan hukum merupakan satu hal terpenting, untuk itu pengumpulan terhadap bahanbahan hukum dilakukan dengan studi dokumentasi, yaitu dengan mencari dan menemukan bahan hukum primer, serta bahan hukum sekunder dan terseier yang berhubungan dengan topik penelitian ini.

\section{HASIL DAN PEMBAHASAN}




\section{A. Prinsip Hukum transaksi Bisnis internasional pada era perdagangan bebas}

Hukum transaksi bisnis internasional terkategori berada dalam ranah hukum privat, sehingga terhadapnya diberikan kebebasan kepada para pihak untuk menentukan isi perjanjian yang menjadi prestasi dalam sebuah perikatan. Meskipun demikian, transaksi bisnis yang dilakukan oleh dua subjek hukum yang berlainan warganegara tersebut harus tetap megindahkan hukum internasional mengenai transaksi bisnis yang mereka lakukan, selain harus memperhatikan kaidah hukum nasional masing-masing negara. Menurut huala adolf ${ }^{1}$, kontak internasional adalah suatu kontrak yang didalamnya ada atau terdapat unsur asing (Foreign element). Unsur asing yang dimaksud diantaranya adalah adanya subjek hukum yang berbeda kewarganegaraan.

Dalam hukum internasional diatur beberapa ketentuan internasional dalam beberapa konvensi internasional mengenai transaksi bisnis internasional. Oleh sebab itu transaksi dagang internaisonal harus mematuhi ketentuan-ketentuan yang dibuat negara-negara dan/atau lembaga-lembaga internasional. Adapun beberapa ketentuan tersebut diantaranya berkaitan dengan tariff pajak / bea ekspor impor, barang (goods) yang boleh diperdagangkan, serta ketentuan-ketentuan tentang asuransi, metode transaksi dan lain sebagainya.

Prinsip-prinsip hukum yang diatur dalam transaksi bisnis internasional mengacu pada prinsip-prinsip hukum perjanjian/kontrak internasional yang disepakati oleh para pihak, dan konvensi perdagangan internasional (international trade convention). Prinsip-prinsip hukum bisnis internasional ini dapat dilihat dari keberlakuan/ sumber hukum kontrak internasional, huala adolf ${ }^{2}$ dalam bukunya menjelaskan bahwa terdapat 7

\footnotetext{
${ }^{1}$ Huala Adolf, 2008, Dasar-dasar Hukum Kontrak Internasional. Bandung. PT. Refika Aditama. HIm 1

${ }^{2}$ Ibid,. hlm. 69
} 
tujuh bentuk hukum yang dapat menajdi sumber hukum kontrak internaisonal, yakni :

1. Hukum Nasional

2. Dokumen Kontrak

3. Kebiasaan-kebiasaan di bidang perdagangan internasional yang terkait dengan kontrak

4. Prinsip-prinsip hukum umum mengenai kontrak

5. Putusan pengadilan

6. Doktrin

7. Perjanjian internasional mengenai kontrak.

Dari ketujuh sumber hukum tersebut, maka dapat dijelaskan bahwa, meskipun kontrak bisnis internasional merupakan ranah hukum privat, dan menerapkan prinsip hukum kebebasan berkontrak dan prinsip kedaulatan, namun tetap harus mengindahkan beberepa sumber hukum kontrak internasional lainnya.

Secara umum, terdapat 2 prinsip-prinsip hukum umum dalam kontrak bisnis internasional yang mendasari terciptanya kontrak bisnis internasional yakni :

1. Prinsip dasar kebebasan berkontrak (freedom of the contract) Bahwa kontrak bisnis internasional dilakukan berdasarkan pada kebebasan para pihak menetukan isi dan prestasi yang akan dituangkan dalam kontrak bisnis internasional. Meskipun diberi kebebasan dalam menentukan prestasi, namun tetap harus memperhatikan sumber hukum kontrak internasinal.

2. Prinsip kedaulatan/supremasi hukum nasional;

Dalam kajian hukum privat, kebebasan juga diberikan pada pemilihan hukum (choise of law), berbeda pada kontrak bisnis nasional, pada kontrak bisnis internaisonal, kedua belah pihak biasannya terlebih dahulu menyepakati pilihan hukum guna 
menundukkan diri pada hukum nasional negara salah satu subjek hukum kontrak bisnis.

Prinsip kedaulatan/supremasi hukum juga dapat diterapkan pada kontrak bisnis yang tidak menentukan pilihan hukum dalam kontraknya. Dengan menggunakan beberapa asas dalam hukum kontrak yang terdapat dalam kaidah hukum perdata internasional. Prinsip-prinsip hukum transaksi bisnis internasional dapat dijumpai pada kaidah hukum perjanjian internasional yang mengatur mengenai ketentuan-ketentuan transaksi bisnis internasional. Adapun ketentuan dalam konvensi internasional tersebut mengenai Contracts for the internasional Sale of Goods (CISG) dan the UNIDROIT Principle of International Contracts Tahun 1994.

Adapun prinsip-prinsip hukum kontrak tersebut diantaranya adalah sebagai berikut :

1. Prinsip kebebasan berkontrak

Prinsip pertama, kebebasan berkontrak, termuat dalam Pasal 1.1 menyatakan bahwa: " The parties are free to enter into a contract and to determine its content.". Pasal ini menegaskan bahwa para pihak diberi kebebasan untuk mengikatkan diri terhadap sebuah kontrak dan bebas untuk menentukan isi dari kontrak tersebut.

Dari prinsip kebebasan berkontrak tersebut dapat dijabarkan lebih lanjut sebagai berikut :

a. The parties are free to enter into a contract;

Bahwa para pihak diberikan kebebasan untuk menundukkan diri atau mengikatkan dirinya terhadap sebuah kontrak yang dibuat. Sehingga dalam unsure ini tidak diperkenankan adanya paksaan dalam menyepakati sebuah kontrak.

b. The parties are free to determine its content; 
Bahwa para pihak diberikan kebebasan untuk menentukan isi dari kontrak yang dibuatnya.

Namun demikian asas kebebasan berkontrak tersebut tetap harus memenuhi prinsip hukum umum yang dapat dalam sumber hukum kontrak internasional. Untuk itu prinsip kebebasan berkontrak didalamnya terdapat mandatory rules, yakni pengecualian-pengecualian terhadap aturan yang memaksa. Mandatory rule dapat dilihat dalam prinsip-prinsip hukum umum kontrak bisnis internasinal dan nasional. Prinsip hukum umum kontrak tersebut adalah membatasi kebebasan membuat kontrak yang telah dengan tegas dilarang oleh hukum internasional maupun hukum nasional masingmasing pelaku usaha. Selain hal tersebut, pengecualian atau pembatasan prinsip kebebasan berkontrak ini juga dilakukan terhadap norma-norma dan kesusilaan yang berlaku dimasing-masing negara pelaku usaha.

Mandatory Rule dalam Principles of international commercial contracts, 1994, UNIDROIT, Article 1.4 "Nothing in these Principles shall restrict the application of mandatory rules, whether of national, internasional or supranational origin, which are applicable in accordance with the relevant rules of private international law.

2. Prinsip pengakuan hukum terhadap kebiasaan bisnis

Prinsip ini termuat dalam Pasal 1.8 prinsip UNIDROIT menyatakan :

(1) The parties are bound by any usage to which they have agreed and by any practices which they have established between themselves.

(2) the parties are bound by a usage that is widely known to and regular observation in international trade by parties in the particular trade concerned except where the application of such usage would be unreasonable 
Prinsip kekuatan mengikat praktek kebiasaan dagang 3 , merupakan prinsip yang disebut pula sebagai keterbukaan terhadap kebiasaan dagang. Pengakuan terhadap praktek kebiasaan ini didasarkan pada pertimbangan bahwa kebiasaan dagang bukan saja secara fakta mengikat tetapi juga karena ia berkembang dari waktu ke waktu.

3. Prinsip itikad baik (good faith) dan transaksi jujur (fair dealing)

Prinsip Itikad baik merupakan prinsip yang abstrak, karena penggunaan prinsip ini dianggap selalu digunakan di awal kesepakatan dilakukan. Prinsip ini termuat dalam Pasal 1.7 yang menyatakan:

(1) each party must act in accordance with good faith and fair dealing in international trade."

(2) The Parties may not exclude or limit this duty

Terdapat tiga unsur ${ }^{4}$ dari prinsip itikad baik dan transaksi jujur, yaitu:

a) Itikad baik dan transaksi jujur sebagai prinsip dasar yang melandasi kontrak;

b) Prinsip itikad baik dan transaksi jujur dalam UPICCs ditekankan pada praktik perdagangan internnasional;

c) Prinsip itikad baik dan transaksi jujur bersifat memaksa.

Dari pasal ini dapat diketahui tujuannya adalah, untuk mendorong diterapkannya prinsip itikad baik (good faith) dan kewajaran (fair dealing) dalam setiap transaksi komersial yang bersifat internasional. Manifestasi upaya mendorong harmonisasi hukum tampak ketika di dalam kontrak atau hukum nasional tidak ditemukan aturan yang diperlukan atau telah terjadi kekosongan hukum (gaps), maka prinsip-prinsip UNIDROIT (The

\footnotetext{
${ }^{3}$ Ibid., HIm. 90

${ }^{4}$ Taryan Soenandar, Prinsip-prinsip UNIDROIT sebagai sumber Hukum Kontrak dan Penyelesaian sengketa bisnis internasional, 2006, HIm. 42
} 
International Institute for the Unification of Private Law) dapat digunakan sebagai rujukan.

Prinsip Itikad baik akan terlihat secara nyata jika telah terjadi wanprestasi dari kesepakatan yang dibuat oleh para pihak.

Pasal 2.15 UPICCs (Unidroit Principles of International Commercial Contracts) mengatur larangan tersebut sebagai berikut :

1. A party is free to negotiate and is not liable for failure to reach an agreement.

2. However, a party who negotiates or breaks off negotiations in bad faith is liable for losses to the other party.

3. It is bad faith, in particular, for a party to enter into or continue negotiations when intending not to reach an agreement with the other party.

4. Prinsip force majeure

Prinsip penting Force Majeure atau keadaan memaksa (juga kadang disebut keadaan kahar) termuat dalam Pasal 7.1.7 Prinsip UNIDROIT. Pasal ini berbunyi sebagai berikut:

"(1) Non-performence by a party is execused if that party proves that the non-performance was due to an impediment beyond its control and that it could not reasonably be expected to have taken the impediament into account at the time of the conclusion of the contract or to have avoided or overcome it or its consequences.

(2) When the impediment is only temporary, the execuse shall have effect for such period as is reasonable having regard to the effect of the impediment on the performance of the contract.

(3) The party who fails to perform must give notice to the other party of the impediment and its effect on its ability to perform. If the notice is not received by the other party within a reasonable time after the party who fails to perform knew or ought to have known of 
the impediment, it is liable for damages resulting from such nonreceipt.

(4) Nothing in this article prevent a party from exercising a right to terminate the contract or to withhold performance or request interest on money due."

Ketentuan mengenai keadaan kahar atau force mejeur dalam Principles UNIDROIT tidak berbeda dengan pemahan yang berlaku pada hukum nasional kita, bahwasanya dikatakan force majeure adalah adanya peristiwa yang terjadi berada di luar kemampuan, dan dengan adanya peristiwa tersebut mewajibkan kepada pihak yang mengalaminya untuk memberitahukan pihak lainnya bahwa telah terjadinya force majeure.

5. Retroactive effect of Avoidance

Bahwa kontrak bisnis memberlakukan prinsip tidak berlaku surut, sebagaimana tercantum dalam Article 3.17 (1). Avoidance takes effect retroactively.

Principles of UNIDROIT menyatakan bahwa kontrak bisnis internasional tidak diminta untuk harus dituangkan secara tertulis, sebagaimana tercantum dalam article 1.2 "nothing in these principles requires a contract to be conclude in or evidenced by writing. it may be proved by any means, including witnesses.

Namun sebaiknya kontrak bisnis interansional dibuatkan secara tertulis hal ini bertujuan untuk memudahkan pembuktian atas telah terjadinya perbuatan hukum yang didalamnya memberi hak dan kewajiban bagi masing-masing pihak untuk menjalankan prestasinya. Meskipun dalam proses membuktikan diijinkan dengan menggunakan alat bukti selain surat, yakni saksi.

\section{B. Kepastian Hukum pada kontrak Bisnis internasional}

Transaksi bisnis internasional merupakan bagian kajian dari hukum perdata internasional, dimana dalam kaidah hukum perdata internasional 
akan menetukan apakah kontrak bisnis internasional tersebut memang harus dilindungi menurut kaidah hukum nasional ataupun kaidah hukum asing.

Globalisasi dalam dunia bisnis telah menimbulkan kompleksitas dan keberagaman transaksi. Kondisi seperti ini menimbulkan tuntutan akan kepastian hukum (legal certainty) dari setiap transaksi. Kondisi seperti diuraikan di atas menjadikan kebebasan berkontrak sebagai paradigma utama dalam hukum kontrak. Kebebasan berkontrak dipandang sebagai penjelmaan hukum (legal expression) prinsip perdagangan bebas. Sama halnya dengan liberalisasi perdagangan, doktrin kebebasan berkontrak dibangun diatas asumsi terdapatnya kekuatan posisi tawar yang sama antara para pihak yang melakukan transaksi. Akibatnya bisa terjadi pihak yang lemah dikuasai oleh pihak yang memiliki posisi tawar yang lebih kuat. Kritikan terhadap doktrin kebebasan berkontrak menyebutkan terjadinya perubahan paradigma hukum kontrak dari kebebasan berkontrak kearah kepatutan. Saat ini kebebasan berkontrak tidaklah berarti kebebasan tanpa batas. Unsur kepastian hukum dalam kebebasan berkontrak diimbangi dengan unsur keadilan (justice) bagi para pihak dalam kontrak

Sebagai salah satu sumber hukum transaksi bisnis internasional, Contracts for the internasional Sale of Goods (CISG) hingga saat ini belum dilakukan ratifikasi oleh Indonesia. Sebagaimana telah diketahui bahwa Indonesia menganut sistem hukum civil law, dimana untuk dapat memberlakukan suatu konvensi internasional/perjanjian internasional harus terlebih dahulu dilakukan proses trasnformasi hukum. Menurut ketentuan konvensi Wina Tahun 1969 tentang perjanjian Internasional dan Undangundang Nomor 24 tahun 2000 tentang Perjanjian Internasional, maka proses transformasi salah satunya dilakukan dengan cara ratifikasi hukum. Sehingga dapat dipastikan bahwa konvensi internasional tersebut dapat memiliki kekuatan mengikat terhadap seluruh masyarakat Indonesia. BPHN telah melakukan kajian dan pembahasan mengenai pentingnya Indonesia segera meratifikasi CSIG, terbukti bahwa November 2013 lalu, BPHN telah 
merampungkan Naskah Akademik Ratifikasi Konvensi PBB mengenai Kontrak Jual Beli Barang Internasional (CISG) yang dipimpin oleh Prof. Hikmahanto Juwana, S.H.,L.LM.,Ph.D.

Dijelaskan dalam naskah akademik $^{5}$ Ratifikasi Konvensi PBB mengenai Kontrak Jual Beli Barang Internasional (CISG), bidang hukum yang penting dalam untuk diperhatikan dalam suatu perdagangan internasional adalah hukum kontrak. Perbedaan pengaturan hukum kontrak (Nasional) dalam suatu transaksi jual beli internasional yang melibatkan pelaku usaha dari dua atau lebih negara yang berbeda tentu akan menimbulkan ketidak pastian hukum.

Berbeda halnya dengan CSIG, walaupun Indonesia telah meratifikasi konvensi Statute of The International Institute For The Unification Of Private Law Peraturan Presiden Republik Indonesia Nomor 59 Tahun 2008 Tentang Pengesahan Statute of The International Institute For The Unification of Private Law (Statuta Lembaga Internasional Untuk Unifikasi Hukum Perdata). Maksud dari Lembaga Internasional untuk Unifikasi Hukum Perdata adalah meneliti cara-cara untuk melakukan harmonisasi dan koordinasi hukum perdata pada Negara-Negara dan kelompok Negara, dan mempersiapkan secara bertahap penerimaan oleh berbagai negara mengenai aturan hukum perdata yang seragam.

Tetapi penggunaan konvensi tersebut dalam hukum nasional merupakan pilihan dan negara masih memiliki kewenangannya untuk melakukan pembatasan terhadap perdagangan atau kerjasama yang dianggap memegang peranan penting terhadap negara. Hal ini tercermin dalam pembatasan terhadap Freedom of Contract dalam beberapa peraturan perundang-undangan di Indonesia.

Kepastian hukum dalam kontrak bisnis internasional dapat dilihat pada kaidah-kaidah hukum perdata internasional, namun kaidah hukum perdata internasional akan menjadi sangat sulit dan membutuhkan waktu yang panjang

${ }^{5}$ BPHN. 2013. Ratifikasi Konvensi PBB mengenai Kontrak Jual Beli Barang Internasional (CISG). HIm. 5 
dalam penyelesaian sengketa wanprestasi, dikarenakan penggunaan kaidah hukum perdata internasioal harus memperhatikan titik taut atau tititk pertalian yang terdapat dalam kontrak bisnis internasional tersebut.

Prinsip-prinsip UNIDROIT memberikan solusi terhadap masalah yang timbul ketika terbukti bahwa tidak mungkin untuk menggunakan sumber hukum yang relevan dengan hukum yang berlaku di suatu negara.Oleh karena itu prinsip-prinsip UNIDROIT digunakan sebagai sumber hukum yang dijadikan acuan dalam menafsirkan ketentuan kontrak yang tidak jelas.Apabila tidak ditemukan aturannya dalam hukum yang berlaku (governing law) maka prinsip-prinsip tambahan, karena prinsip-prinsipnya diambil dari kebiasaan dan praktik yang seragam secara internasional.Sebagian besar prinsip-prinsip UNIDROIT dimaksudkan seperangkat aturan penyeimbang untuk digunakan di seluruh dunia tanpa memperhatikan tradisi hukum dan kondisi ekonomi politik.Dari segi formal, prinsip ini menghindari penggunaan terminologi yang digunakan dalam sistem hukum tertentu.Selain itu prinsip ini merujuk pada CISG sehingga dilihat dari segi substansinya prinsip-prinsip UNIDROIT bersifat fleksibel. ${ }^{6}$

\section{KESIMPULAN}

Adapun kesimpulan sementara pada penelitian ini adalah :

1. Prinsip-prinsip hukum transaksi bisnis internasional dapat dijumpai pada kaidah hukum perjanjian internasional yang mengatur mengenai ketentuan-ketentuan transaksi bisnis internasional. Adapun ketentuan dalam konvensi internasional tersebut mengenai Contracts for the internasional Sale of Goods (CISG) dan the UNIDROIT Principle of International Contracts Tahun 1994.

Adapun prinsip-prinsip hukum kontrak tersebut diantaranya adalah sebagai berikut :

1. Prinsip kebebasan berkontrak

${ }^{6}$ lbid, hlm 10. 
kebebasan berkontrak, termuat dalam Pasal 1.1

2. Prinsip pengakuan hukum terhadap kebiasaan bisnis Prinsip ini termuat dalam Pasal 1.8 prinsip UNIDROIT

3. Prinsip itikad baik (good faith) dan transaksi jujur (fair dealing)

Prinsip Itikad baik merupakan prinsip yang abstrak, karena penggunaan prinsip ini dianggap selalu digunakan di awal kesepakatan dilakukan. Prinsip ini termuat dalam Pasal 1.7

4. Prinsip force majeure

Prinsip penting Force Majeure atau keadaan memaksa (juga kadang disebut keadaan kahar) termuat dalam Pasal 7.1.7 Prinsip UNIDROIT.

\section{Retroactive effect of Avoidance}

Bahwa kontrak bisnis memberlakukan prinsip tidak berlaku surut, sebagaimana tercantum dalam Article 3.17 (1).

2. Kepastian hukum dalam kontrak bisnis internasional dapat dilihat dari sumber hukum kontrak bisnis internasional. Bahwasannya ketika pelaku usaha yang berbeda kewarganegaraan melakukan transaksi bisnis internasional, akan berkonseksuensi terhadap penundukan hukum salah satu negara pelaku usaha.

penggunaan konvensi UNIDROIT dalam hukum nasional merupakan pilihan dan negara masih memiliki kewenangannya untuk melakukan pembatasan terhadap perdagangan atau kerjasama yang dianggap memegang peranan penting terhadap negara. Hal ini tercermin dalam pembatasan terhadap Freedom of Contract dalam beberapa peraturan perundang-undangan di Indonesia.

\section{SARAN}

1. Teori Prepare to contract sebagai upaya preventif harus dilakukan dengan mengindahkan dan memasukkan semua prinsip-prinsip hukum kontrak internasional. Hal tersebut akan memudahkan kedua belah pihak (pelaku usaha) dalam memahami dan 
menyelesaikan perselisihan, jika dikemudian hari terdapat wanprestasi.

2. Perlu adanya ratifikasi hukum CSIG sehingga para pelaku bisnis akan memiliki kepastian hukum dalam menjalankan transaksi bisnis internasional. Kepada mereka dapat ditetapkan satu hukum yang sama sehingga tidak akan terjadi penafsiran hukum dan keterpaksaan terhadap salahsatu pihak untuk menundukkan diri pada salah satu hukum negara lain..

\section{DAFTAR ACUAN}

Adirini, Pujayanti, Perbatasan Wilayah Indonesia dalam Perspektif (Editor : Poltak Partogi Nainggolan) Tiga Putra Utama

Adolf, Huala, 2004, Perjanjian penanaman Modal dalam Hukum Perdagangan Internasional (WTO), PT. Raja Grafindo Persada, Jakarta 2008, Dasar-dasar Hukum Kontrak Internasional. Bandung. PT. Refika Aditama, Jakarta

Amiruddin dan Zainal Asikin, 2003, Pengantar Metode Penelitian Hukum, PT. Raja Grafindo Persada, Jakarta,

Abdul, Sani, 2007, Buku Pintar Kepabeanan, Gramedia:Jakarta

Abdulkadir, Muhammad, 2007, hukumPerikatan,Bandung : Alumni,

Agustina, Rosa dkk, 2012, Hukum Perikatan (Law Of Obligations), Pustaka larasan, Bali 
Assihiddiqie, Jimly dkk, 2012, Teori Hans kelsen Tentang Hukum, Konstitusi Press, Jakarta

Bagus Wyasa Putra, Ida, 2000, Aspek-aspek Hukum Perdata Internasional dalam Transaksi Bisnis Internasional, PT. Adika refitama, Bandung

Desimilasi Kebijakan perdagangan dengan Negara mitra dalam rangka peningkatan perdagangan Lintas Batas dengan Negara tetangga.

Hutagalung, Sophar Maru, 2013, Kontrak Bisnis di Asean, Pengaruh Sistem hukum Comman Law dan civil Law, Sinarr Grafika, Jakarta

Peter Mahmud Marzuki, 2008, Penelitian Hukum, Cetakan Keempat, Kencana Prenada Media Group, Edisi Kesatu, Jakarta, ,

Muhammad, Abdulkadir,2000, Hukum Acara Perdata, PT. Citra Aditya Bakti,

Retnowulan Sutantio,Ny.1979,Hukum Acara Perdata dalam teori dan Praktek, CV. Mandar Maju: Jakarta;

Simanjutak. P. N. H. 2009, Pokok-Pokok Hukum Perdata Indonesia, Djambatan: Jakarta:

Suharnoko,2008,Hukum Perjanjian Teori dan Analisa Kasus ,Prenada Media Group:Jakarta:

Subekti, 1982, Aneka Perjanjian: Alumni: Bandung :

Subekti,Pokok-Pokok Hukum Perdata:PT. Inter Masa : Jakarta; 1987 
Sudikno Mertokusumo, 2001, Penemuan Hukum - Suatu Pengantar.Yogyakarta : Liberty,

Soerjono Soekanto dan Sri Mamudji, 2003, Penelitian Hukum Normatif, Jakarta : Raja Grafindo Persada,

Soeroso, R, 1992, Perbandingan Hukum Perdata, cetakan ke 5 2012, Sinar Grafika, Jakarta

Sood, Muhammad, 2012, Hukum Perdagangan Internasional, Rajawali Press, Jakarta

Triwulan Tutik, Titik, 2008, Hukum Perdata dalam system Hukum Nasional, Kencana, Jakarta

Universitas Bangka Belitung, 2008, Kontrak Dagang Hukum Internasional berdasarkan Analisis Yuridis. www.ubb.ac.id.:

Wirjono Prodjodikoro.R. 2000,Azas-azas Hukum Perjanjian, CV. Mandar Maju: Jakarta;

Naskah Akademik Ratifikasi Konvensi PBB Contracts for the internasional Sale of Goods CSIG, Tahun 2013

Naskah Akademik Rancangan Undang-undang UNIDROIT

Peraturan Presiden Republik Indonesia Nomor 59 Tahun 2008 Tentang Pengesahan Statute Of The International Institute For The Unification Of Private Law (Statuta Lembaga Internasional Untuk Unifikasi Hukum Perdata) 
